\title{
Studies on the Roles of Boron in Growth and Sugar- Transport Processes of Sugarcane ${ }^{t}$
}

\author{
Rafael Montalvo.Zapata \\ INTRODUCTION
}

The essentiality of boron (B) for growth and development of higher plants is generally recognized, but the precise roles it contributes remained obscure prior to the mid-1950's (30). The research of Gauch, Dugger and associates $(16,29)$ then indicated that boron enhances uptake and translocation of sugars. They proposed a micronutrient union with sugars giving an ionizable sugar-borate complex which more readily moves through cellular membranes than sugar alone (29). Subsequent studies by Dugger, Humphreys, and Calhoun $(13,14)$ implied a direct involvement of boron in the enzymic reactions of sucrose and starch biosynthesis. In 1967, Lee and Aronoff (25) suggested that borate combines with 6-phosphogluconic acid to form an enzyme-inhibitor complex which regulates phenol synthesis, thereby preventing the typical necrosis and ultimate death of B-deficient plants.

Van den Honert (31) and Martin (26) pioneered boron-nutrition studies in sugarcane during the early 1930's. Maximum growth and quality was not attained in the absence of boron. Detailed boron-deficiency symptoms were described by Martin (26) in 1934 and by Evans in 1956 (15). In 1963, Samuels and Cibes-Viadé (28) reported a general decline of growth and quality in boron free plants propagated in the greenhouse. Sugarcane studies by Bowen in Hawaii have stressed the physiological and biochemical effects of variable boron supply $(10,12)$, and borate ionic species absorption (11). Work by Humbert et al. (23) in Peru has shown that excessive boron is restrictive against sugar and tonnage yields. In Puerto Rico, Acin-Diaz and Alexander (1) observed borate effects on the rate of sucrose diffusion from storage tissues bathed in distilled water.

Greenhouse and laboratory studies of boron activity in immature sugarcane were completed recently at this Station. Evidence is presented herein of discrete growth, enzyme, and sugar-transport roles in plants having controlled water and nutrient supplies.

1 Manuseript submitted to Editorial Board April 6, 1972.

assistant Chemist, Agricultural Experiment Station, University of Puerto Rico, Mayagüez Campus, Río Piedras, P.R. The author acknowledges the advice of Dr. A. G. Alexander, Plant Physiologist, with regard to the experiments herein described and for his review of the manuseript. 


\section{MATERIALS AND METHODS}

All plants were greenhouse-propagated in quartz sand with carefully controlled water and nutrient supplies. Two nutrient regimes were initiated 4 weeks after germination and were continued for $51 / 2$ months. One constituted a complete supply of macro- and micronutrients, ${ }^{3}$ while boron was withheld from the second.

The sand, a commercial "silica shot," was washed thoroughly with tap water, treated overnight with $0.1 \mathrm{~N} \mathrm{HCl}$, and washed again with tap water. It was leached with distilled water following transfer to glazed, 2-gallon containers. One-eye cuttings of the interspecific variety P.R. 980 were planted on February 7, 1971 and watered once daily until March 5. The water supply for boron-free plants was purified with a Barnstead distillation apparatus equipped with a tin-lined condensation chamber and Pyrex glass or polyethylene storage tanks." Tap water was used in "feeding" and watering the complete nutrient series. Each container received daily 1 liter of water at 8:00 a.m. and 1 liter of nutrient solution at 1:00 p.m. Water alone was given twice daily on weekends. Plants were arranged in a randomized block design with 4 replicates of each nutrient regime.

After 51/2 months, four plants were harvested from each replicate for growth, quality, and enzyme analyses. Green-weight and internode-expansion values were recorded immediately. Millable stalks were ground the following day with a small laboratory mill for Brix, polarization, purity, and sucrose-percent-cane analyses. Additional stalk samples were frozen for later use in sugar diffusion studies. Leaf ranks -1 to +5 were prepared individually for sugar, boron, and enzyme analyses by quick-freezing and lyophilization methods previously described (2). Immature storage tissues were similarly prepared for sugar and enzyme determinations. Extraction and analytical procedures for sucrose, acid phosphatase, ATP-ase, acid invertase and $\beta$-amylase were conducted as described previously (2), with only minor modifications. Foliar boron determinations were performed by the Central Analytical Laboratory using the colorimetric method of Hatcher and Wilcox (22).

Additional laboratory work included paper- and gas-liquid chromatographic analyses of tissue extracts and sugar-borate preparations, plus sugar-diffusion experiments with normal and B-deficient storage tissues. Principal features of the chromatography methods were given in an earlier report (6). In the present study, potential sugar-borate residues were

${ }^{3}$ Macronutrient levels, expressed as meg./1., were as follows: $\mathrm{NO}_{\mathrm{z}}, 15.0 ; \mathrm{PO}_{4}, 10.0$; $\mathrm{K}, 8.0 ; \mathrm{Ca}, 8.0 ; \mathrm{Mg}, 2.0$; and $\mathrm{S}, 2.0$. Micronutrient levels, expressed as p.p.m., were: $\mathrm{Fe}, 1.0 ; \mathrm{B}, 0.05 ; \mathrm{Cu}, 0.02 ; \mathrm{Mn}, 0.50 ; \mathrm{Zn}, 0.05 ;$ and $\mathrm{Mo}, 0.01$.

Contaminate boron levels were in the order of 0 to 0.001 p.p.m. for distilled water and 0.002 to 0.018 p.p.m. for tap water. 
reacted with trimethylsylil reagent, following lyophilization of their aqueous solutions, and resolved in acid-washed SE-30 columns at $170^{\circ}$ or $230^{\circ} \mathrm{C}$. Sugar-diffusion experiments utilized rind-free tissue slices bathed in water, Tris buffer, or aqueous additive solutions in accordance with the methods of Acin-Diaz and Alexander (1). Frozen tissues were also examined in several diffusion experiments.

All replicated data were submitted to statistical analysis of variance.

\section{RESULTS}

Growth and quality parameters were significantly altered by the low-B regime. Evidence was found of boron-enzyme relationships and boron participation in sucrose biosynthesis. Chromatographic and sugar-diffusion data suggest that borate ions may participate in the movement of sugars across storage tissue membranes. Taken together with the findings of other

TABLE 1.-Foliar boron conlent as a function of leaf rank in immalure sugarcane supplied with variable boron in sand culture ${ }^{1}$

\begin{tabular}{lccccccc}
\hline \multirow{2}{*}{ Nutrient regime } & \multicolumn{7}{c}{ Boron content (p.p.m.) for leaf rank- } \\
\cline { 2 - 8 } & -1 & 0 & +1 & +2 & +3 & +4 & +5 \\
\hline Complete & 17.5 & 14.5 & 19.3 & 20.8 & 19.5 & 20.5 & 16.8 \\
-B & $3.0^{* *}$ & $2.0^{* *}$ & $5.0^{* *}$ & $4.3^{* *}$ & $6.0^{* *}$ & $4.8^{* *}$ & $4.3^{* *}$ \\
\hline
\end{tabular}

1 Each figure is the computed mean of 4 replicates.

** Significant difference $(P<.01)$ between values within the corresponding leaf rank.

authors, the present results are consistent with the operation of borate at several discrete sites along the sugarcane source-to-sink system.

\section{GROWTH AND QUALITY RESPONSES}

Visible symptoms of boron deficiency were not attained; however, an insufficiency of the element for normal growth and development was evidenced by low foliar boron values (table 1) and divergent growth responses (table 2). Leaf analyses revealed consistently low boron levels regardless of leaf rank. There was no evidence of the element's transport from B-suffcient to B-insufficient leaves, as postulated by Oertli and Richardson (27). Withholding boron produced a major growth decline as shown by greenweight values in table 2 . In millable stalks, low boron consistently reduced lateral joint expansion, which led to perceptible thinning of the cane stems, while internode elongation was only slightly repressed (fig. 1).

Significant quality changes were produced by low boron in both leaf and storage tissues. Foliar sucrose values were consistently lower in all but 
the oldest leaf rank measured (fig. 2). Paper chromatography of aqueous leaf extracts revealed no evidence of sugars or sugar analogs in low-B leaves other than those normally found in B-sufficient leaves (fig. 3). Milled-juice and immature storage tissue analyses showed significant losses for polarization, purity, and sucrose values within the low-B regime (table 3). Similar observations were reported by Samuels and Cibes-Viadé (28). Quality

TABLE 2.-Growth responses of immalure sugarcane supplied with variable boron in sand cullure 1

\begin{tabular}{ccccc}
\hline \multirow{2}{*}{ Nutrient regime } & \multicolumn{4}{c}{ Growth values at 51/2 months- } \\
\cline { 2 - 5 } & $\begin{array}{c}\text { Total fresh } \\
\text { weight }\end{array}$ & Stalk weight & $\begin{array}{c}\text { Internode } \\
\text { length }\end{array}$ & $\begin{array}{c}\text { Internode } \\
\text { diameter }\end{array}$ \\
\hline & $(G . /$ planl $)$ & $($ G./stalk $)$ & (Inches) & $($ mm.) \\
Complete & 478 & 269 & 3.8 & 15.4 \\
-B & $293^{* *}$ & $152^{* *}$ & 3.5 & $13.0^{* *}$ \\
\hline
\end{tabular}

1 Each figure is the computed mean of 4 replicates. rank.

** Significant difference $(P<.01)$ between values within the corresponding leaf

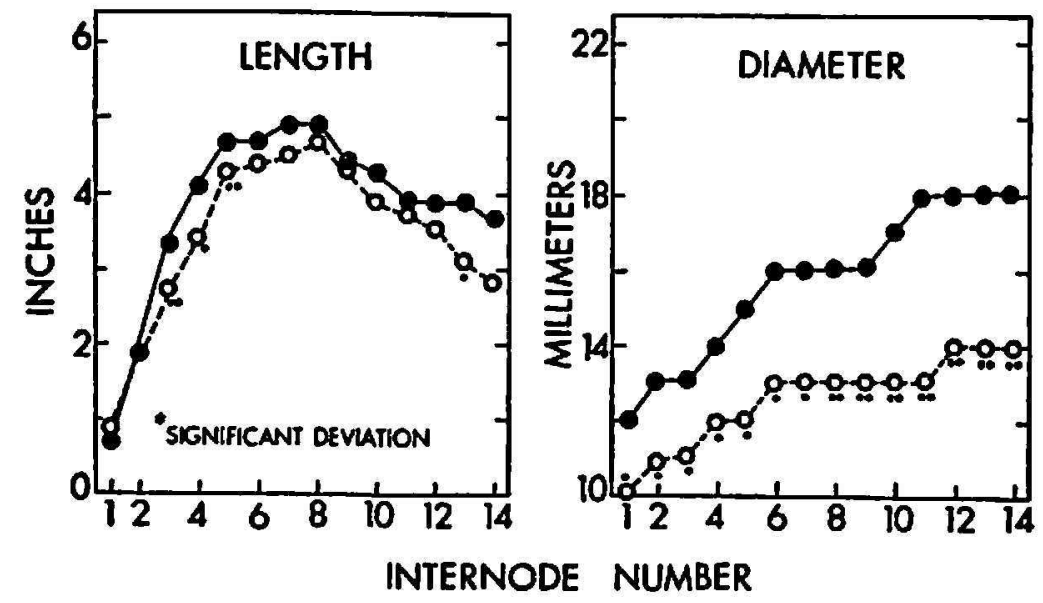

FrG. 1.-Internode expansion in immature sugarcane propagated with variable boron supply in sand culture. Symbols: (๑) Complete nutrient regime; $(O)$ minus boron.

measurements thus suggest boron activity at both ends of the sugarcane source-to-sink system.

\section{FNZYME AND PROTEIN RESPONSES TO LOW BORON}

In contrast to the macronutrient ( $N$ and $P$ )-induced enzyme changes discussed by Bieleski (9), several enzyme responses of a non-substrate induction type were produced within the low-B regime. $\beta$-amylase activity was significantly reduced by low boron in leaf ranks +1 to +4 (table 4 ) and in immature storage tissue (table 5). Acid invertase was similarly re- 


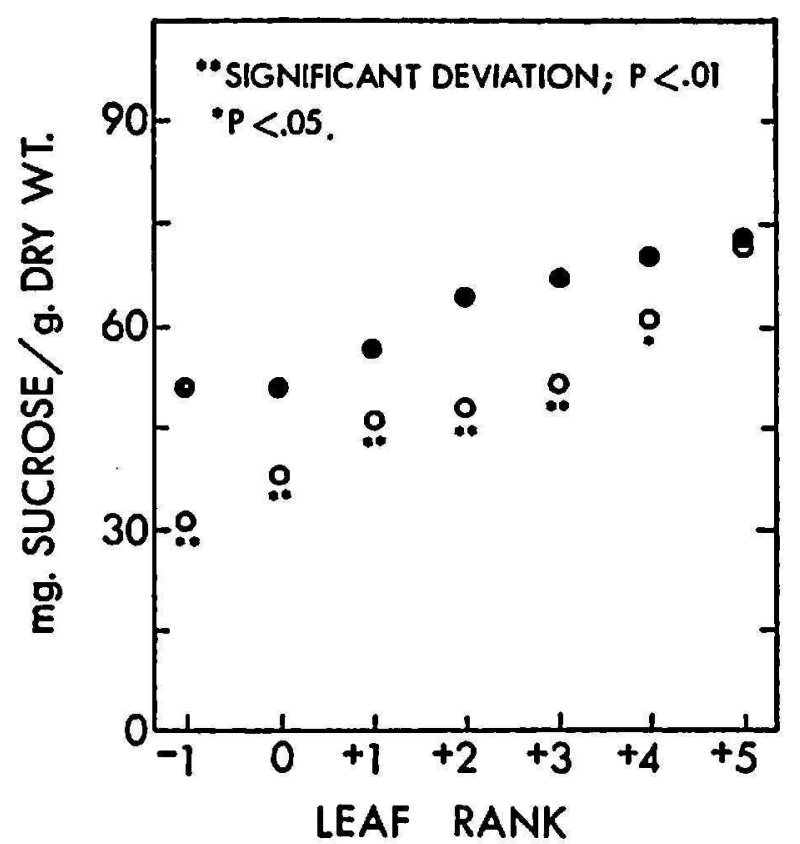

FIG. 2.-Sucrose content of sugarcane leaves propagated with variable boron supply in sand culture. Symbols: $(\bullet)$ Complete nutrient regime; $(O)$ minus boron.

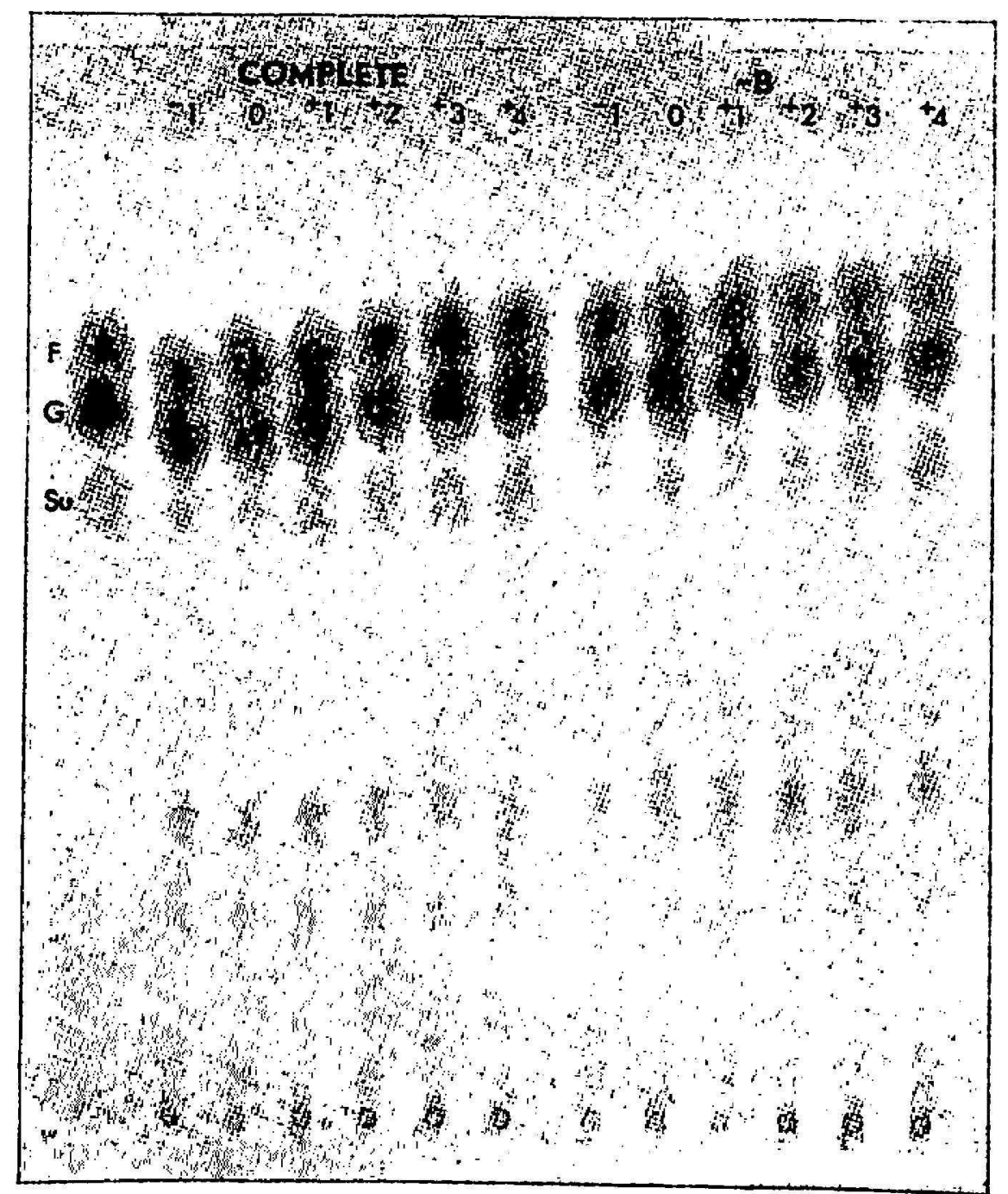

Fra. 3.-Paper chromatography of aqueous leaf extracts illustrating sucrose, fructose and glucose components of sugarcane leaves propagated with variable boron supply in sand culture. Letters F, G, and Su at the left-hand margin identify authentic fructose, glucose, and sucrose, respectively. Numbers denote leaf rank. 
pressed in the absence of normal boron supplies. Earlier work failed to show an appreciable borate effect on foliar amylase in vitro (4). Acid phosphatase and ATP-ase were not consistently affected among leaf ranks but were increased in immature storage tissue. Water-soluble protein was moderately

TABLE 3.-Effects of variable boron supply on the juice qualily of sugarcane propagated in sand culture ${ }^{1}$

\begin{tabular}{|c|c|c|c|c|c|}
\hline \multirow{2}{*}{ Nutrient regime } & \multicolumn{4}{|c|}{ Millable-stalk parameters } & \multirow{2}{*}{$\begin{array}{c}\text { Immature } \\
\text { storage tissue } \\
\text { mg. sucrose/g. } \\
\text { dry wt. }\end{array}$} \\
\hline & Brix & Pol & Purity & $\begin{array}{c}\text { Sucrose- } \\
\text { percent-cane }\end{array}$ & \\
\hline Complete & 13.4 & 40.7 & 75.3 & 3.83 & 148 \\
\hline$-B$ & 11.9 & $33.8^{*}$ & $70.7^{*}$ & $2.60^{*}$ & $108^{*}$ \\
\hline
\end{tabular}

1 Each figure is the computed mean of 4 replicates.

* Significant difference $(P<.05)$ between values within the corresponding leaf rank.

TABLE 4.-Prolein content and specific-activity values for leaf enzymes of immature sugarcane supplied with variable boron in sand culture ${ }^{1}$

\begin{tabular}{|c|c|c|c|c|c|c|c|c|}
\hline \multirow{2}{*}{ Parameter } & \multirow{2}{*}{$\begin{array}{c}\text { Nutrient } \\
\text { regime }\end{array}$} & \multicolumn{7}{|c|}{ Leaf rank- } \\
\hline & & -1 & 0 & +1 & +2 & +3 & +4 & +5 \\
\hline \multirow{4}{*}{$\begin{array}{l}\text { Protein (mg./g. dry } \\
\text { wt.) } \\
\text { Acid phosphatase }\end{array}$} & Complete & 3.7 & 3.6 & 4.4 & 4.7 & 6.2 & 6.0 & 6.3 \\
\hline & $-\mathbf{B}$ & 3.3 & 4.2 & $5.5^{*}$ & $8.0^{*}$ & 7.5 & $8.3^{*}$ & 8.0 \\
\hline & Complete & 34.1 & 26.3 & 16.6 & 8.6 & 5.7 & 5.2 & 4.5 \\
\hline & $-\mathbf{B}$ & $41.1^{*}$ & 22.6 & $10.3^{*}$ & $6.3^{*}$ & 5.1 & $4.2^{*}$ & 4.6 \\
\hline \multirow[t]{2}{*}{ ATP-ase } & Complete & 55.7 & 44.2 & 29.4 & 12.5 & 8.9 & 7.6 & 6.1 \\
\hline & & 64.4 & 47.2 & $19.4^{*}$ & 10.5 & 8.5 & 7.1 & 6.5 \\
\hline \multirow[t]{2}{*}{$\beta$-amylase } & Complete & 266 & 265 & & 154 & & 65.8 & 61.8 \\
\hline & $-\mathbf{B}$ & 301 & 229 & $63.5^{* *}$ & $58.5^{* *}$ & $40.1^{* *}$ & $28.3^{* *}$ & 48.8 \\
\hline
\end{tabular}

1 Each figure is the computed mean of 4 replicates. Leaves were harvested at $51 / 2$ months.

** Significant difference $(P<.01)$ and $*(P<.05)$ between values within the corresponding leaf rank.

TABLE 5.-Water-soluble protein and enzyme values for sugarcane storage tissue propagated in sand culture with variable boron supply ${ }^{1}$

\begin{tabular}{lccccc}
\hline \multirow{2}{*}{ Nutrient regime } & $\begin{array}{c}\text { Water-soluble } \\
\text { protein (mg./g. } \\
\text { dry wt.) }\end{array}$ & \multicolumn{4}{c}{ Specific activity values for enzyme- } \\
\cline { 5 - 7 } & 30.2 & $\begin{array}{c}\text { Acid } \\
\text { phosphatase }\end{array}$ & ATP-ase & $\beta$-amylase & $\begin{array}{c}\text { Acid } \\
\text { invertase }\end{array}$ \\
\hline Complete & 3.2 & 9.2 & 142 & 9.1 \\
-B & 22.0 & $11.8^{* *}$ & $12.9^{* *}$ & $84.1^{*}$ & $6.0^{*}$ \\
\hline
\end{tabular}

1 Each figure is the computed mean of 4 replicates.

** Significant difference $(P<.01)$ and * $(P<.05)$ between values within the corresponding leaf rank. 
increased in several leaf ranks but not in immature storage tissue. Bowen's (12) finding of large protein concentrations in B-deficient tissue was therefore not substantiated. However, the present data were consistent with the view that boron may participate in enzymic reactions incident to sucrose biosynthesis $(14,3)$.

\section{SUGAR DIFFUSION AND ACCUMULATION PROCESSES}

Earlier studies with normal storage tissues revealed that borate can increase the rate of sugar diffusion from tissues bathed in distilled water (1). Similar experiments with low-B tissues suggest that boron may affect both the diffusion and reaccumulation of sucrose, either via permanent struc-

TARLE 6.-Sucrose diffusion from sugarcane slorage tissue propagated with variable boron supply in sand cullure ${ }^{1}$

\begin{tabular}{|c|c|c|c|c|c|c|c|}
\hline \multirow{2}{*}{ Bathing medium } & \multirow{2}{*}{$\begin{array}{l}\text { Nutrient } \\
\text { regime }\end{array}$} & \multicolumn{6}{|c|}{ Percent of total storage sucrose exited at hour- } \\
\hline & & 0 & 2 & 6 & 12 & 18 & 24 \\
\hline \multicolumn{8}{|c|}{ Mature storage tissue } \\
\hline \multirow[t]{2}{*}{ Water } & Complete & 0 & 1.30 & 2.70 & 2.18 & 1.06 & 0 \\
\hline & $-\mathbf{B}$ & 0 & 2.87 & 4.10 & 3.20 & 2.51 & 0 \\
\hline \multirow[t]{2}{*}{ Tris buffer } & Complete & 0 & 1.51 & 3.69 & 3.22 & 3.24 & 3.27 \\
\hline & $-\mathbf{B}$ & 0 & 1.91 & 2.76 & 2.76 & 2.64 & 2.73 \\
\hline \multicolumn{8}{|c|}{ Immalure slorage tissue } \\
\hline \multirow[t]{2}{*}{ Water } & Complete & 0 & 1.08 & 2.38 & 1.56 & 0.58 & 0 \\
\hline & $-B$ & 0 & 2.12 & 2.80 & 1.63 & 0.72 & 0 \\
\hline \multirow[t]{2}{*}{ Tris buffer } & Complete & 0 & 1.38 & 3.40 & 3.50 & 3.75 & 3.87 \\
\hline & $-B$ & 0 & 0.64 & 1.40 & 1.78 & 1.49 & 1.48 \\
\hline
\end{tabular}

1 Mean values for duplicate flasks.

tural effects on the cell wall or by regulation of invertases active in sugar accumulation processes. Low-B data summarized in table 6 show a greater sugar efflux and slower reentry for mature tissues bathed in distilled water. In Tris buffer ( $\mathrm{pH} 7.0$ ), where acid invertase is repressed (21,24), the low-B effect was eliminated and no appreciable reaccumulation of sucrose occurred. In immature storage tissue, where acid invertase is highly concentrated, low boron briefly increased sugar efflux in water while consistently repressing sugar movement in Tris buffer. Conversely, since Tris buffer affected only the reaccumulation of sugar in control tissues, i.e., in tissues propagated with adequate boron, while low borate repressed sugar efflux, a boron role is implied in passive sugar diffusion which is independent of boron-invertase relationships in active sugar accumulation. Subsequent 
diffusion experiments supported this contention with physical and chemical evidence.

Physical evidence of boron activity in sucrose movement across cell membranes was obtained with frozen stem samples. All frozen materials were structurally damaged as evidenced by large increases in sucrose efflux to distilled water (fig. 4). However, low-B tissues frozen and thawed prior to incubation retained sucrose more effectively than frozen "complete" tissues. Moreover, a higher proportion of the diffused sugar managed to reenter tissues harvested from the low- $B$ regime.

Chemical evidence of boron activity was obtained by adding DNP (2,4-dinitrophenol), ATP, and borate to the bathing medium (table 7).

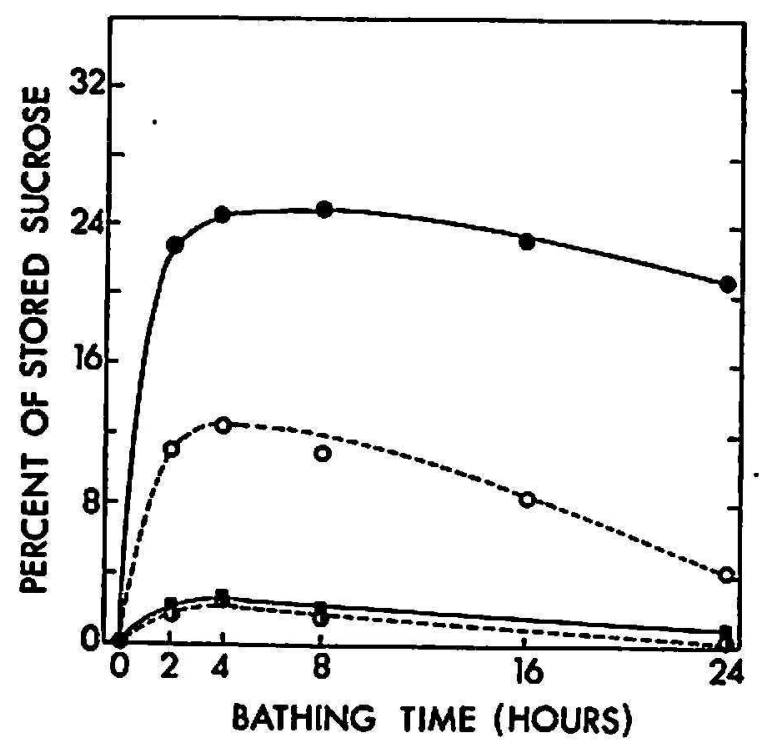

Fra. 4.-Effects of boron regime and freezing injury on sucrose efflux and reaccumulation rates in immature storage tissue propagated in sand culture. Symbols: (๑) Frozen "complete" tissues; (O) frozen, low-B; (D) fresh "complete" tissues; (C) fresh, low-B.

The presence of DNP vastly increased sucrose diffusion and prevented its reentry regardless of tissue origin; however, the chemical's effect was consistently more pronounced in low-B tissues. DNP is a respiratory inhibitor which presumably blocked the generation of ATP needed for active sugar storage. The low-B effect thus implies a boron role in ATP synthesis, and hence a weakened energy-generating mechanism in low-B tissues which was less able to withstand the inhibitor treatment. This contention was strengthened when ATP added to a water bathing medium increased sugar efflux and reaccumulation in both "complete" and low-B tissues (table 7). Addition of borate increased diffusion from low-B tissues in the approximate order of magnitude reported previously (1) with B-sufficient tissues. However, added boron failed to reduce the discrepancy between "com- 
plete" and low-B tissues. This may signify a long-term effect on tissue structure which cannot be remedied by short-term exposure to supplemental borate. This interpretation is consistent with the internode-expansion data shown in figure 1.

\section{DISCUSSION}

Present evidence points to spatially and biochemically discrete roles of boron in the sugarcane source-to-sink system. Insufficient supply of the micronutrient will restrict sucrose formation in leaves while altering sucrose accumulation and retention processes in stem tissue. There is an attendant loss of growth capacity as cane quality declines. Within this framework several views merit further consideration: (a) In a nutritional sense, low-B

TABLE 7.-Effecls of DNP, ATP, and borale on sucrose eflux from mature storage tissue propagated with variable boron supply in sand culture

\begin{tabular}{|c|c|c|c|c|c|c|c|c|c|c|}
\hline \multirow{2}{*}{ Bathing medium } & \multirow{2}{*}{$\underset{\text { regime }}{\text { Nutrient }}$} & \multicolumn{9}{|c|}{ Percent of stored sucrose exited at hour- } \\
\hline & & 0 & $3 / 2$ & 1 & 2 & 4 & 0 & 12 & 18 & 24 \\
\hline Distilled water & $\begin{array}{l}\text { Complete } \\
\text {-B }\end{array}$ & $\begin{array}{l}0 \\
0\end{array}$ & $\begin{array}{l}0.38 \\
0.66\end{array}$ & $\begin{array}{l}0.52 \\
0.80\end{array}$ & $\begin{array}{l}0.76 \\
1.17\end{array}$ & \begin{tabular}{|l|}
1.02 \\
1.46
\end{tabular} & $\begin{array}{l}1.41 \\
2.14\end{array}$ & $\begin{array}{l}0.94 \\
1.43\end{array}$ & $\begin{array}{l}0.65 \\
1.02\end{array}$ & $\begin{array}{l}0.35 \\
0.60\end{array}$ \\
\hline DNP $\left(2 \times 10^{-3} \mathrm{M}\right)$ & $\begin{array}{l}\text { Complete } \\
-\mathrm{B}\end{array}$ & $\begin{array}{l}\mathbf{0} \\
\mathbf{0}\end{array}$ & $\begin{array}{l}0.75 \\
2.01\end{array}$ & $\begin{array}{l}3.08 \\
5.83\end{array}$ & $\begin{array}{r}6.92 \\
15.76\end{array}$ & $\begin{array}{r}23.53 \\
39.15\end{array}$ & $\begin{array}{l}32.03 \\
52.96\end{array}$ & $\begin{array}{l}46.63 \\
59.07\end{array}$ & $\begin{array}{l}46.58 \\
58.80\end{array}$ & $\begin{array}{l}46.19 \\
55.53\end{array}$ \\
\hline $\operatorname{ATP}\left(2.5 \times 10^{-8} \mathrm{M}\right)$ & $\begin{array}{l}\text { Complete } \\
-\mathbf{B}\end{array}$ & $\begin{array}{l}0 \\
0\end{array}$ & $\mid \begin{array}{l}0.46 \\
0.76\end{array}$ & $\begin{array}{l}0.85 \\
1.80\end{array}$ & $\begin{array}{l}1.37 \\
3.12\end{array}$ & \begin{tabular}{|l|}
2.38 \\
4.06
\end{tabular} & $\begin{array}{l}2.68 \\
4.32\end{array}$ & $\begin{array}{l}1.34 \\
1.89\end{array}$ & $\begin{array}{l}0.76 \\
1.31\end{array}$ & $\begin{array}{l}0.36 \\
0.77\end{array}$ \\
\hline $\begin{array}{l}\text { Boric acid }\left(5 \times 10^{-3}\right. \\
\text { M) }\end{array}$ & $\begin{array}{l}\text { Complete } \\
-B\end{array}$ & $\begin{array}{l}0 \\
0\end{array}$ & $\begin{array}{l}0.32 \\
0.46\end{array}$ & $\left|\begin{array}{l}0.42 \\
0.77\end{array}\right|$ & $\begin{array}{l}0.55 \\
1.63\end{array}$ & \begin{tabular}{|l|}
0.96 \\
2.69
\end{tabular} & $\begin{array}{l}1.28 \\
2.92\end{array}$ & $\begin{array}{l}0.91 \\
1.63\end{array}$ & $\begin{array}{l}0.65 \\
1.28\end{array}$ & $\begin{array}{l}2.27 \\
0.51\end{array}$ \\
\hline
\end{tabular}

1 Mean values for duplicate flasks.

effects on growth and quality are decisive within the realm of "hidden hunger," well in advance of visual deficiency; (b) foliar sucrose losses reflect changes in biosynthetic capacity rather than transport potential; (c) boron may participate in both physico-chemical and enzyme-mediated mechanisms of intracellular transport.

As with most crop plants, experienced cane growers become sliilled in diagnosing nutritional disorders by visual inspection. However, the low-B plants herein described gave no outward evidence that any nutrient had become limiting against growth or quality development. A complete mineral analysis for any leaf rank up to +5 would have alerted the plantation manager to insufficient boron. On the other hand, elemental B content per se could not have gauged adequately the boron restriction against discrete processes in leaf and stem tissues. Moreover, micronutrient diagnosis is by no means a universal practice among the world's sugar planters. 
Leaf sucrose decline in low-B plants is not accountable to translocation processes owing to the simultaneous loss of sugar from stem tissues. Contrary to low macronutrient stresses which appear to slacken sugar transport $(19,20,5)$, the low-B effect is best explained by a weakened sucrose biosynthesis apparatus. A partial explanation is found in the work of Dugger and Humphreys (13) showing an intimate involvement of boron

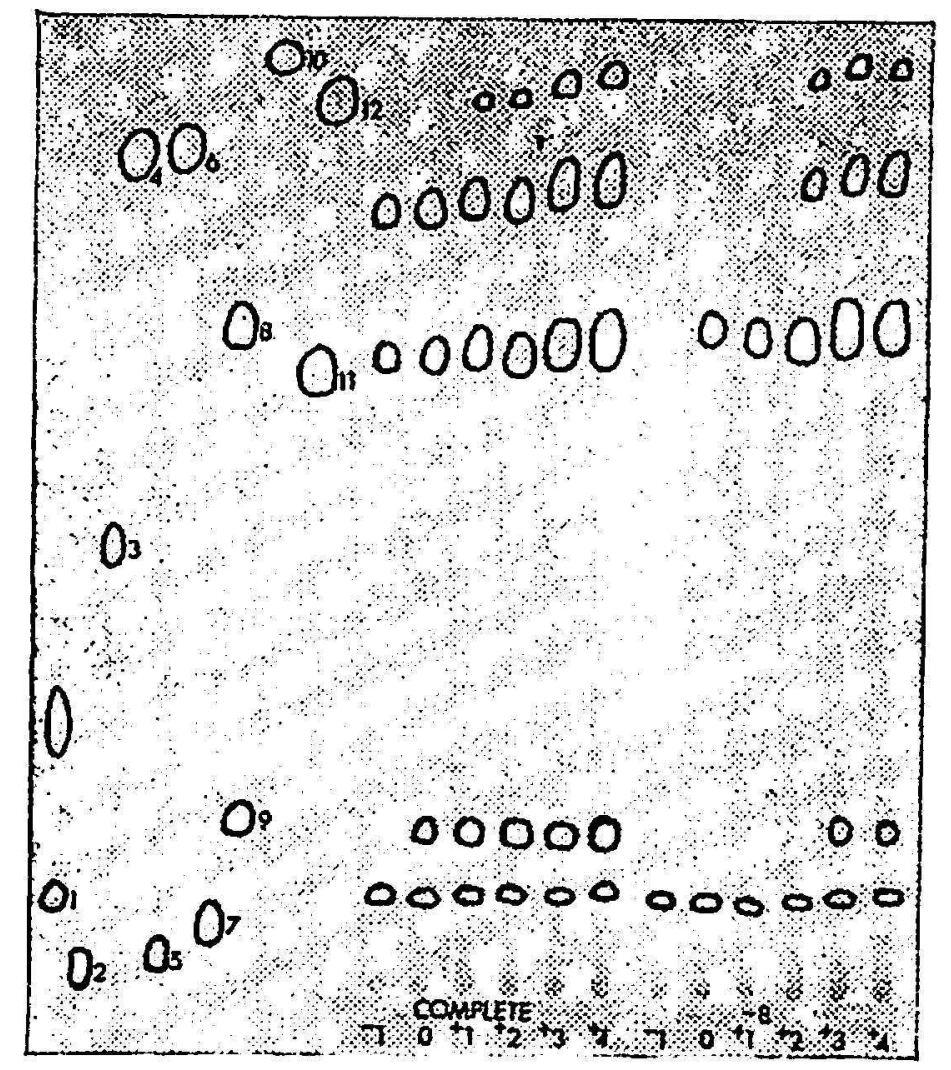

FIG. 5.-Paper chromatogram of aqueous leaf extracts from sugarcane plants given complete and low-B nutrient regimes, showing the distribution of U.V.-absorbing compounds in one dimension. Numbered circles at the left-hand side identify the following authentic compounds spotted in $10 \mathrm{ug}$. quantities: 1, Flavin adenine dinucleotide; 2 , triphosphopyridine nucleotide; 3 , glucoseamine; 4 , adenosine; 5 , adenosine triphosphate; 6 , uridine; 7 , uridine diphosphate glucose; 8 , amino uracil; 9 , thymidine; 10 , thymine; 11, cytosine; 12 , purine. Solvent: Butanol-pyridine-water $(6: 4: 3 \mathrm{v} / \mathrm{v})$; irrigation time, 30 hours.

in enzymic reactions supporting sucrose biosynthesis. The present B-induced changes in foliar amylase lend support to this view (table 4), while amylase, ATP-ase, and acid invertase changes in chloroplast-free storage tissue suggest that low-B effects are not confined to the photosynthetic unit (table 5). Ultraviolet scanning of chromatographed leaf extracts revealed an apparent failure of B-insufficient leaves to maintain sugar-precursor pools comparable to "complete" leaves (fig. 5). Derivatives of uridine and adenosine are of particular interest in this context. Although 
nucleotide components were not individually identified, the normal increase of most fluorescent fractions with increasing leaf rank and sucrose content was repressed by low boron in the order of 2 to 4 leaf ranks. Again, the micronutrient effect was quite the opposite of that produced earlier by low $\mathrm{N}, \mathrm{P}, \mathrm{K}$ and $\mathrm{Ca}(5)$, wherein leaf sucrose and nucleotide levels increased simultaneously. Bowen (12) has also reported reduced levels of soluble nucleotides in B-deficient leaves.

The initial efflux of sugars from storage tissues bathed in water was shown by Bieleski $(7,8)$ to be a passive, non-metabolic process operating in equilibrium with a second-phase active uptake. Present effects of low boron on both efflux and reentry rates can be rationalized broadly in terms of abnormal tissue structure, which in turn will conceivably alter sugar flow in both directions independently of metabolic considerations. Growth and physical-injury data presented above tend to support this view. However, the loss of acid invertase in low-B tissues (table 5) offers a direct means for boron to govern sugar flow in the accumulation processes which are dependent upon sucrose inversion $(17,18)$. Further to this, the present small evidence of boron activity in ATP generation, if strengthened, would give boron commanding positions in hexose-hexose interconversion, sucrose-P formation, and rate of energy-expenditure for sugar accumulation against large concentration gradients.

Throughout these studies the possibility of boron operating as a "carrier" in sugar storage processes was at no time discounted. In theory, boron might also participate in foliar transport processes such as veinal loading or transcendence of phloem sieve plates in the basipetal flow of sucrose. Whether active in source or sink regions, a key problem has been to show that a chemical union of boron and sugar can form under physiological conditions, withstand transport across a barrier membrane, and dissociate readily at the opposite membrane surface.

Some evidence of sugar-borate complex formation was presently obtained by gas-liquid chromatography (figs. 6 and 7). Sucrose resolution peaks shown in figure 6,A to $\mathrm{D}$, suggest that a sucrose-borate complex had formed as the boric acid level was raised from 0 to 100 micromoles per $\mathrm{ml}$. With the SE-30 column employed, consistent peak depression may be valid evidence of a new configuration with higher molecular weight. Individual examination of the fructose and glucose moieties gave evidence that each can unite with borate (fig. 7). These data suggest a borate potential to react with each end of the sucrose molecule, and with each of the three sugars having major roles in the sugar storage processes of sugarcane. Whether or not such configurations may form and dissociate within the physiological environment of a cell membrane is a valid point of departure for new studies by cell-culture methods. 

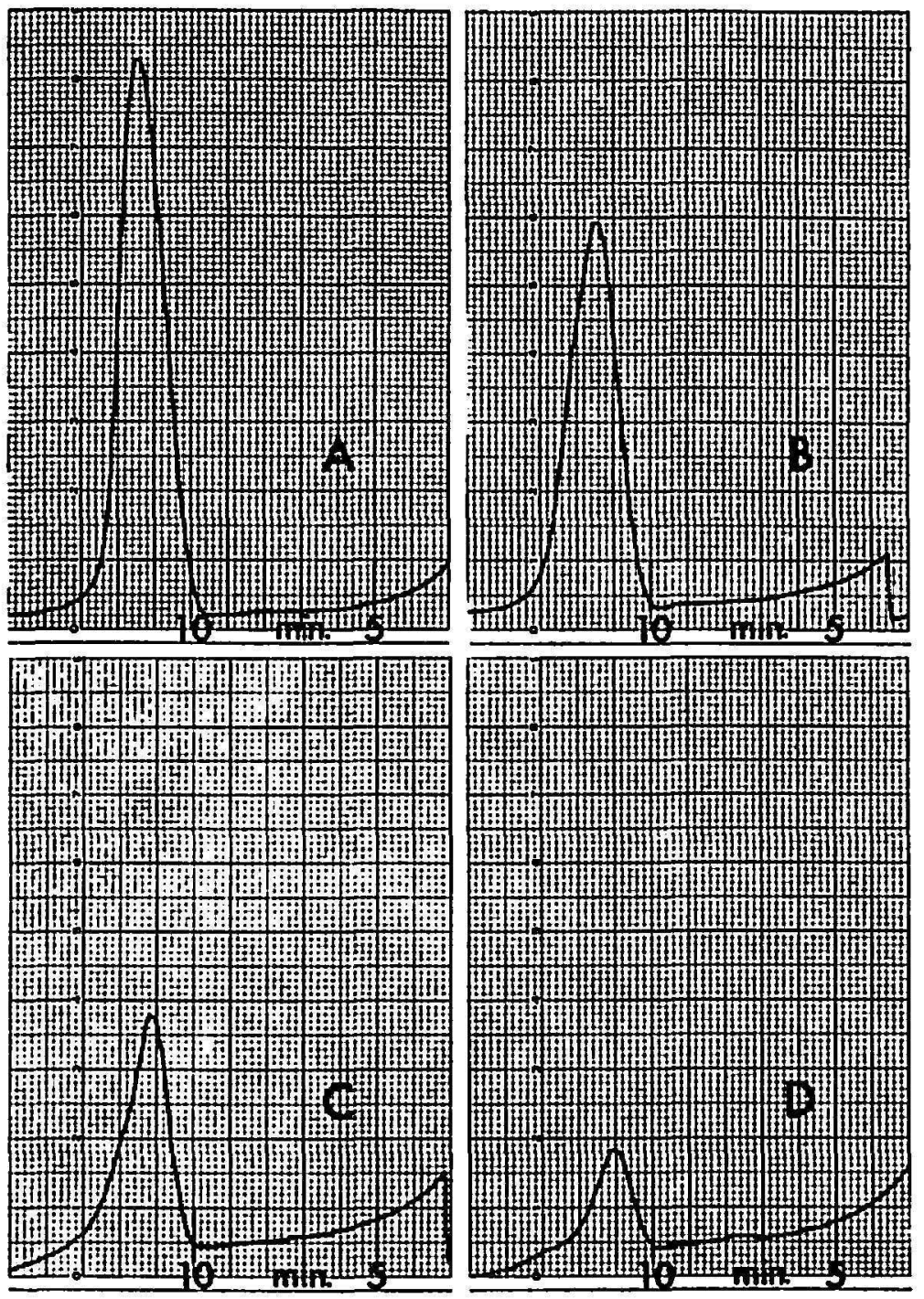

Fra. 6.-Gas-liquid chromatography of aqueous sucrose-borate preparations. A-C: Sucrose retention peaks obtained in the presence of $0,25,50$, and $100 \mu$ moles of borate/ml., respectively. Column: SE-30 (3\%, w/w) coated on Chromosorb W. Temperature: $230^{\circ} \mathrm{C}$.

\section{SUMMARY}

Sugarcane growth and quality responses to low boron supply were examined with immature plants propagated in sand culture over a period of $5 \frac{1}{2}$ months. Plants receiving only traces of boron in once-distilled water experienced significant growth and quality losses without developing visual B-deficiency symptoms. Growth decline was largely confined to lateral internode expansion. Boron insufficiency lowered sucrose production in leaves and significantly altered the rates of sugar transport in bathing storage-tissue slices. Evidence of biochemical boron roles in leaves and of physical-biochemical roles in storage tissues is presented. The importance of major micronutrient restrictions within the realm of "hidden hunger" is discussed. 

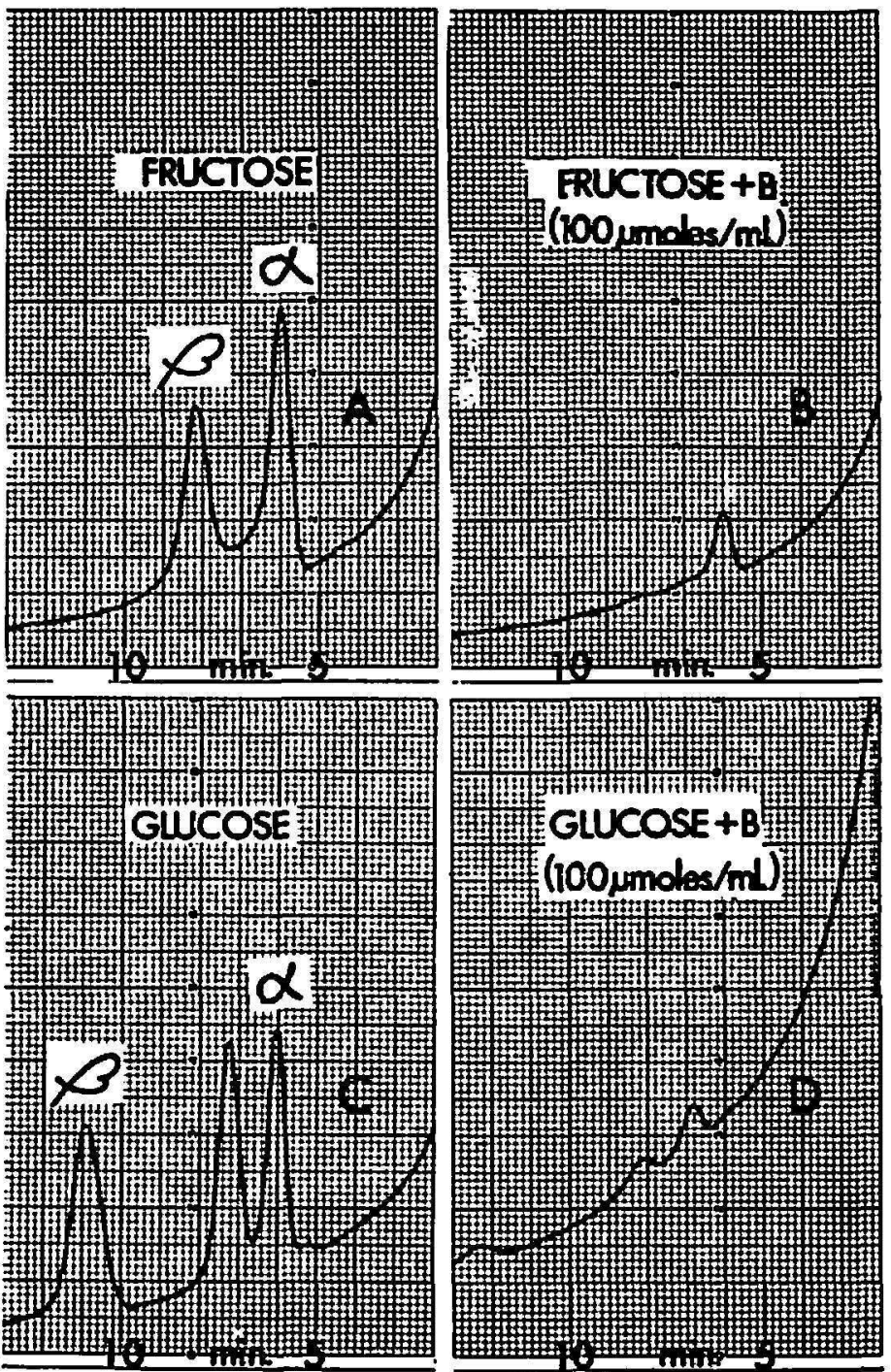

Fra. 7.-Gas-liquid chromatography of aqueous hexose-borate preparations. A \& B: Fructose retention peaks obtained with 0 and $100 \mu \mathrm{moles}$ of borate/ml., respectively. C \& D: Glucose retention peaks with 0 and $100 \mu$ moles of borate $/ \mathrm{ml}$., respectively. Column: SE-30 $(3 \%, w / w)$ coated on Chromosorb W. Temperature: $230^{\circ} \mathrm{C}$.

\section{RESUMEN}

Se examinaron las respuestas en términos de crecimiento y calidad en plantas de caña de azúcar cultivadas en arena y sometidas a un suministro deficiente en boro. Durante un periodo de $5, \zeta$ meses, las plantas suministradas con solamente trazas de boro en agua destilada fueron afectadas adversa y significativamente en cuanto a su crecimiento y calidad sin haber desarrollado síntomas visuales de deficiencia de boro. El descenso en el crecimiento se limitó mayormente a la expansión lateral del entrenudo. La insuficiencia de boro hizo bajar la producción de sacarosa en las hojas y alteró significativamente la tasa en el movimiento del azácar en tajadas del tejido reservante sumergidas en agua. Se presentan pruebas de la función bioquímica del boro en las hojas y de su función físico-bioquímica en el tejido reservante. Se discute la importancia que tiene la restricción de los principales micronutrimentos dentro de lo que se designa como "hambre latente." 


\section{LITERATURE CITED}

1. Acín-Diaz, N., and Alexander, A. G., Studies on sugar diffusion from sugarcane storage tissue, J. Agr. Univ. P.R. 51(3): 253-266, 1972.

2. Alexander, A. G., Sucrose-enzyme relationships in immature sugarcane as affected by varying levels of nitrate and potassium supplied in sand culture, J. Agr. Univ. P.R. 48 (3): 165-231, 1964.

3. - The biosynthesis of sucrose, J. Agr. Univ. P. R. 48 (4): 265-83, 1965.

4. - Hydrolytic proteins of sugarcane: Amylase, J. Agr. Univ. P. R. 49 (3): 308$24,1965$.

5. - Nucleotides of sugarcane: Increased nucleotide content of leaves as a function of nutritional stress, J. Agr. Univ. P.R. 51 (3): 228-37, 1967.

6. Alexander, A. G., Acín-Diaz, N., and Montalvo-Zapata, R., Inversion control in sugarcane juice with sodium meta-silicate, Proc. Int. Soc. Sugar Cane Technol. 14 (in press).

7. Bieleski, R. L., The physiology of sugarcane. III. Characteristics of sugar uptake in slices of mature and immature storage tissue, Aust. J. Biol. Sci. 13: 203-20, 1960.

8. - The physiology of sugarcane. IV. Effects of inhibitors on sugar accumulation in storage tissue slices, Aust. J. Biol. Sci. 13: 221-31, 1960.

9. - Enzyme changes in plants following changes in their mineral nutrition, Int. Colloquium Plant Analysis and Fertilizer Problems (Tel Aviv) 6: (preprint, 1970).

10. Bowen, J. E., Some physiological effects of variable boron and zinc levels on sugarcane, Haw. Sugar Technol. Rept. pp. 35-9, 1967.

11. - Absorption of borate ionic species by Saccharum officinarum L., Plant \& Cell Physiol. 10: 227-30, 1969.

12. - Biochemical and physiological effects of boron in sugarcane, Proc. Int. Soc. Sugar Cane Technol. 14: (in press).

13. Dugger, W. M., Jr., Humphreys, T. E. and Calhoun, B., The influence of boron on starch phosphorylase and its significance in translocation of sugars in plants, Plant Physiol. 32: 364-70, 1957.

14. Dugger, W. M., Jr., and Humphreys, T. E., Influence of boron on enzymatic reactions associated with biosynthesis of sucrose, Plant Physiol. 35 : 523-30, 1960.

15. Evans, $H$., Elements other than $N, P, K$, in the mineral nutrition of sugarcane, Proc. Int. Soc. Sugar Cane Technol. 10: 473-508, 1959.

16. Gauch, H. G., and Dugger, W. M., Jr., The role of boron in the translocation of sucrose, Plant Physiol. 28: 457-66, 1953.

17. Glasziou, K. T., Accumulation and transformation of sugars in sugarcane. Origin of glucose and fructose in the inner space, Plant Physiol. 36: 175-9, 1961.

18. - Accumulation and transformation of sugars in sugarcane stalks. Mechanism of inversion of sucrose in the inner space, Nature 193: 1100, 1962.

19. Hartt, C. E., Effect of nitrogen deficiency upon translocation of ${ }^{14} \mathrm{c}$ in sugarcane, Plant Physiol. 46: 419-22, 1970.

20. - Effect of potassium deficiency upon translocation of ${ }^{14} \mathrm{c}$ in detached blades of sugarcane, Plant Physiol. 45: 183-7, 1970.

21. Hatch, M. D., Sacher, J. A., and Glasziou, K. T., The sugar accumulation cycle in sugarcane. I. Studies on the enzymes of the sugar cycle, Plant Physiol. 38: 338-43, 1963.

22. Hatcher, J. T., and Wilcox, L. V., Colorimetric determination of boron using Carmine, Anal. Chem. 22 (4): 567-9, 1950. 
23. Humbert, R. P., Bahme, R. B., Fernández, E. D., and Thompson, I. I., Overcoming boron and salinity problems in growing sugarcane in the tambo valley of Peru, Sugar y Azucar 65 (9): 32-4, 1970.

24. Humphreys, T. E., and Garrard, L. A., The effect of Tris-(hydroxymethyl) aminomethane on sucrose storage in and leakage from corn scutellum slices, Phytochem 8: 1,055-64, 1969.

25. Lee, S., and Aronoff, S., Boron in plants: A biochemical role, Science 158: 79899, 1967.

26. Martin, J. P., Boron deficiency symptoms in sugarcane, Haw. Plant. Rec. 38: 95-107, 1934.

27. Oertli, J. J., and Richardson, W. F., The mechanism of boron immobility in plants, Physiol. Plant. 23 (1): 108-16, 1970.

28. Samuels, G., and Cibes-Viadé, H., Influence of mineral deficiences on the growth and yield of sugarcane, J. Agr. Univ. P. R. 47 (2): 61-75, 1963.

29. Sisler, E. C., Dugger, W. M., Jr., and Gauch, H. G., The role of boron in the translocation of organic compounds in plants, Plant Physiol. 31: 11-17, 1956.

30. Skok, J., The role of boron in the plant. Chapter 15 in: Trace Elements edited by C. A. Lamb, O. G. Bentley and J. M. Beattie, Academic Press, Inc., New York, N. Y., pp. 227-48, 1958.

31. Van Den Honert, T. H., Onderzoekingen over de voedingsphysiologie van het suiherriet, Arch. Suikerind. Ned. Indië 40: 1,539-1,608, 1932. 